\title{
Research on the Relationship between Exploratory Behavior and Consumer Values using Eye Tracking Gaze Data
}

\author{
Mei Nonaka ${ }^{1}$ \\ Graduate School of Science and \\ Engineering, Chuo University \\ Bunkyo-ku, Tokyo \\ Japan
}

\author{
Kohei Otake ${ }^{2}$ \\ School of Information and \\ Telecommunication Engineering \\ Tokai University, Minato-ku \\ Tokyo, Japan
}

\author{
Takashi Namatame ${ }^{3}$ \\ Faculty of Science and Engineering \\ Chuo University, Bunkyo-ku \\ Tokyo, Japan
}

\begin{abstract}
In recent years, the popularity of e-commerce has witnessed a significant uptick. Physical apparel stores need to implement measures that focus on the behavioral experience of shopping at physical stores, a trait that e-commerce lacks. The purpose of this paper is to clarify the relationship between customer values and product search behavior and proposed product placement and customer service methods based on their values. We used questionnaire data on the values of customer purchasing to perform factor analysis and cluster analysis. Moreover, we extracted the product search behavior using eyetracking gaze data from an apparel physical store. The results showed that product search behavior differed based on three types: trend cluster, self-esteem cluster, and conservative cluster. Finally, we proposed product placement in a store considering the features of these clusters.
\end{abstract}

Keywords-Consumer values; eye tracking; factor analysis; cluster analysis

\section{INTRODUCTION}

In recent years, the popularity of e-commerce has witnessed a significant uptick. According to a market study on ecommerce [1], the e-commerce rate for clothing and apparel was $12.96 \%$. This rate was higher than the average electronic commerce conversion rate of $6.76 \%$ for all industries. As for the change in the use of physical apparel stores over the past three years [2], 32.2\% of the respondents indicated that the number of items that have "decreased a lot" or "decreased a little". From this result, we found that the opportunity to use physical apparel stores decreased. Furthermore, in the same survey, the top three answers for "characteristics of physical stores actually visited" were "trying it in direct contact," "buying it on the spot and take it home," and "shopping with family and friends." Therefore, it is necessary to develop marketing strategies that take advantage of the strength of physical apparel stores. Physical apparel stores need to implement measures that focus on the behavioral experience of shopping at physical stores, a trait that e-commerce lacks. One of the major differences between physical stores and ecommerce is the ability to experience the store environment and to receive customer service [3]. Improving the services and merchandising offered by physical stores can help improve the store image, and in addition, such improvement increases customer satisfaction $[4,5]$. In order to improve these services and merchandising, it is necessary to clarify the customer service required by customers. Therefore, we focused on the relationship between customer values and customer purchasing behavior. Since the use of eye tracking is effective in visualizing purchasing behavior [6], we conducted an experiment using eye tracking devices in this study. In the first part of the paper, we discussed related research on the relationship between values and purchasing behavior, and related research on the eye tracking case used in the analysis, and finally, we proposed product placement and customer service methods.

\section{LITERATURE REVIEW}

To improve sales in youth clothing purchases, Matsumoto et al. [7] stressed the importance of improving the environment inside the store and customer service skills of its employees. Hence, the two key takeaways from this study are store environment and customer service. In their study on the hotel industry, Ando et al. [8] indicated that customer service requirements differ depending on the values of customers. Therefore, capturing customer value should serve as a guideline for customer service and product placement in physical stores so as to fully use the advantages of behavioral experience of a physical store. In the area of eye tracking research, the role of gaze information on purchasing has been studied [9]. By using eye tracking, it is possible to visualize what information is important in purchasing. Zuschke, N. et al. [10] about research on eye tracking suggested that in-store marketing activities would encourage product selection. Bialkova S. et al. [11] conducted an experiment in a laboratory and a supermarket and suggested that placement is an important determinant in a storefront environment. Thus, the information obtained from the experiment in physical stores can be useful. There are many studies that use eye tracking for fashion, for example, understanding the purchasing patterns of mobile consumers [12], understanding the information about online shopping [13], and evaluating the design of products [14]. However, in the research on shopping using eye tracking, there are few examples of viewpoint observation experiments in physical stores of fashion brands. Therefore, in this study, we conducted viewpoint observation experiments in physical store and analyzed them using the eye-tracking data obtained. 


\section{PURPOSE OF THIS STUDY}

The purpose of this study is to classify the relationship between customer value and product search behavior. Specifically, we used questionnaire data on the values of customer purchasing to perform cluster analysis. Next, we extracted the product search behavior using eye-tracking gaze data from an apparel physical store. Based on these results, we compared and analyzed clusters and propose customer service and product placement methods based on customer values.

\section{DATA}

\section{A. Questionnaire Data of Customer Value}

We used questionnaire data about the life index conducted in 2015. The target items included 23 items about fashion and values for purchasing. Questions about fashion include those about the quality and value of clothes, the way people choose clothes, and how they appear in those clothes. Questions about purchasing include questions about how people shop, how they choose, and how they think about products. The rating was based on a five-level scale (1: Not applicable at all, 5: Exactly applicable). This study included a total of 4946 people: 4930 women in their 20s and 30s, who were the subjects of questionnaire data analysis and 16 other who cooperated in the viewpoint observation experiment.

\section{B. Viewpoint Observation Data at Apparel Stores}

We conducted a consumer behavior experiment using a gaze-measuring device at a roadside apparel store on October 15 and 17, 2019 in Tokyo, Japan. Considering that the main target of the target brand in the store was for women in their 20 s and 30s and fashion clothing involvement was significantly affected by a consumer's gender and age [15], we conducted this experiment with 10 women in the 20s under the same conditions. The store deals chiefly in bags, clothes, accessories, wristwatches, and shoes. Women's products could be found at the $1 \mathrm{~F}$ and $2 \mathrm{~F}$ floors. Fig. 1 and Fig. 2 show the layout of the store. Table I and Table II list the product shelves on each floor. We used “Tobii Pro Glasses 2" [16] to record eye tracking during the experiment. This device can move freely while wearing and records what the subjects are looking at. Moreover, when we analyzed the recording data, we used "Tobii Pro Lab" [17] to process the recording data. In order to unify the experimental conditions, the subjects wearing the eye tracking device looked around all floors in the store for $20 \mathrm{~min}$. Before the experiment, we asked the subjects to answer a questionnaire about their preferences and characteristics. As the after-questionnaire once the experiment was over, we asked impressive items and items that they wanted. The study by Saijo et al. [18] was used as reference to create the experimental procedure and questionnaires.

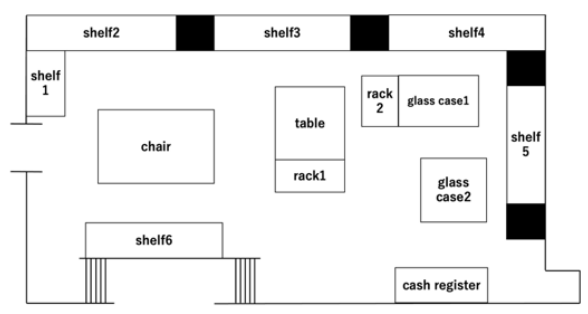

Fig. 1. Layout at $1 \mathrm{~F}$.

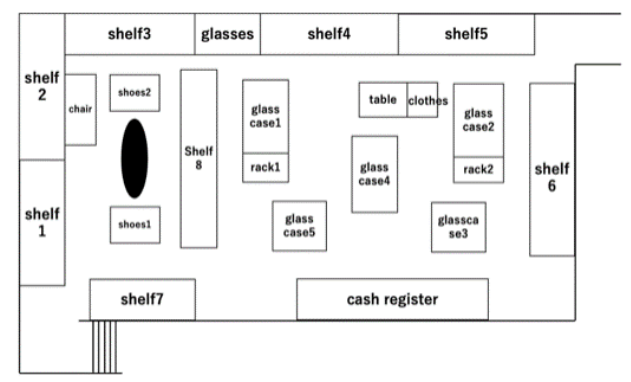

Fig. 2. Layout at $2 \mathrm{~F}$.

TABLE I. THE PRODUCt SHELVES List AT 1F

\begin{tabular}{|l|l|}
\hline $\begin{array}{l}\text { The Product } \\
\text { Shelves }\end{array}$ & Kinds of Products \\
\hline Shelf 1 & Collaboration Products \\
\hline Shelf 2 & New Arrivals, Handbags, Tote Bags, Backpacks \\
\hline Shelf 3 & Handbags, Tote Bags \\
\hline Shelf 4 & Pass Cases, Wallets, Handbags, Shoulder Bags \\
\hline Shelf 5 & Shoulder Bags, Boots, Handbags, Backpack, Body Bags \\
\hline Shelf 6 & Shoulder Bags, Backpacks, Tote Bags, Sneakers, for Men \\
\hline Chair & Handbags, Sneakers \\
\hline Table & T-shirts, Handbags, Wallets \\
\hline Glass Shelf 1 & $\begin{array}{l}\text { Wallets, Pass Cases, iPhone Cases, Key Cases, Pouches, } \\
\text { Key Rings }\end{array}$ \\
\hline Glass Shelf 2 & Wristwatch \\
\hline Rack 1 & Small Shoulder Bags \\
\hline Rack 2 & Large Shoulder Bags \\
\hline
\end{tabular}

TABLE II. The Product Shelves List at 2F

\begin{tabular}{|l|l|}
\hline $\begin{array}{l}\text { The Product } \\
\text { Shelves }\end{array}$ & Kinds of Products \\
\hline Shelf 1 & Sneakers, Boots \\
\hline Shelf 2 & Small Handbags, Sneakers \\
\hline Shelf 3 & Sandals, Boots, Handbag \\
\hline Shelf 4 & Small Handbags, Tote Bags, iPhone Cases \\
\hline Shelf 5 & Small Handbags, Shoulder Bags, Wallets \\
\hline Shelf 6 & Medium Handbags, Shoulder Bags, Sneakers, Backpacks \\
\hline Shelf 7 & Handbag, Shoulder Bags, Mini Wallets, Boots \\
\hline Shelf 8 & Boots, Pumps \\
\hline Glasses & Sunglasses \\
\hline Table & Handbags, Backpacks, Body Bags, Sneakers \\
\hline Clothes & T-shirts, Jackets \\
\hline Glass Case 1 & $\begin{array}{l}\text { Pass Cases, Key Cases, Wallets, iPhone Cases, } \\
\text { Pouches, Key Rings, Handbags }\end{array}$ \\
\hline Glass Case 2 & Wallets, Key Cases \\
\hline Glass Case 3 & Wristwatches \\
\hline Glass Case 4 & Accessories \\
\hline Glass Case 5 & Wristwatches \\
\hline Rack 1 & Small Shoulder Bags \\
\hline Rack 2 & Large Shoulder Bags \\
\hline Shoes 1 & Sneakers \\
\hline Shoes 2 & Sandals, Pumps \\
\hline
\end{tabular}




\section{ANALYSIS OF THE RELATIONSHIP BETWEEN CUSTOMER VALUES AND PRODUCT SEARCH BEHAVIOR}

This section describes the analysis results and the considerations regarding the values. The analysis flow is shown in Fig. 3. First, we conducted a factor analysis using questionnaire data to derive the basic values of fashion and purchasing. We categorize consumer values by referring to the flow of analysis in the study by Ando et al. [8]. In addition, we referred to the papers by Kimura et al. [19] and Matsuoka et al. [20] that used factor analysis and cluster analysis in the analysis of values. To classify customers into groups based on their values, we conducted a cluster analysis based on the results of the factor analysis [21]. Next, we conducted three kinds of analyses to extract, compare, and analyze consumer search behavior for each cluster. Finally, we propose customer service and product placement methods based on customer values.

\section{A. Derivation and Typification of Basic Values Related to Fashion and Purchasing}

Factor analysis is a multivariate analysis method used for finding common factors hidden in multivariate data. We executed the minimum residue method and promax rotation for 23 items of questionnaire data on living indicators. From the results of the screen plot, we identified six factors. Since we deleted five items for which the factor loading was not sufficient, we ended up with 18 items, and the explanation rate for variance was $44 \%$. Table III lists the resulting factor loadings. We named each factor based on the characteristics of the questionnaire items.
The show-off factor was named after the response to wanting to attract attention in fashion. The quality importance factor was named after the response that emphasized quality. The innovator factor was named based on the importance placed on the new products. The faddism factor was named based on responses about how people around them saw them. The commitment factor was named after thinking about and buying things. The intuition factor was named based on the responses to impulse buying. Next, to classify customers based on their values, we conducted a hierarchical cluster analysis. Hierarchical cluster analysis is a statistical analysis method that collects similar items from a large group and divides them into groups. Based on the results of the factor analysis of the basic values of fashion and purchasing, we calculated the factor score using the regression method. To examine the tendency of respondents to the factor scores of six factors, we performed a cluster analysis using the Ward method and classified questionnaire respondents into three clusters based on the results of the dendrogram. We used the Euclidean distance as the distance between the data. The results are presented in Table IV and Fig. 4.

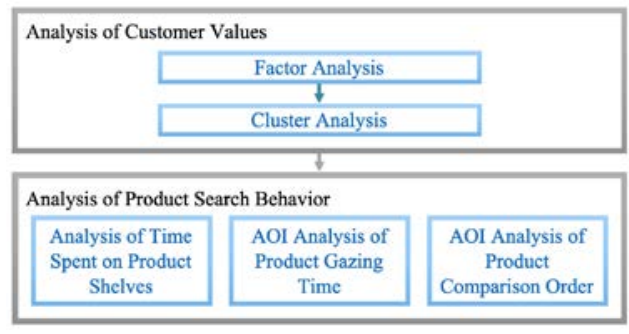

Fig. 3. The Analysis Flow in this Paper.

TABLE III. QUESTIONNAIRE ITEMS ON VALUES SELECTED BY FACTOR LOADINGS

\begin{tabular}{|c|c|c|c|c|c|c|}
\hline \multirow[b]{2}{*}{ Questionnaire Items } & \multicolumn{6}{|c|}{ Factor Loadings } \\
\hline & Show-off & Quality-oriented & Innovator & $\begin{array}{l}\text { Faddis } \\
\text { m }\end{array}$ & $\begin{array}{l}\text { Commitme } \\
\text { nt }\end{array}$ & $\begin{array}{l}\text { Intuitiv } \\
\text { e }\end{array}$ \\
\hline I want to attract attention in fashion. & 0.982 & -0.034 & 0.055 & -0.111 & -0.083 & -0.111 \\
\hline I want to choose clothes that I can use for as long as possible. & -0.084 & 0.714 & -0.084 & 0.062 & -0.017 & 0.018 \\
\hline $\begin{array}{l}\text { I want to choose good quality clothes. } \\
\text { I want to handle them carefully. }\end{array}$ & 0.304 & 0.679 & 0.023 & -0.091 & -0.056 & -0.002 \\
\hline I want to use good things carefully for as long as possible. & -0.132 & 0.607 & 0.032 & -0.007 & 0.148 & 0.046 \\
\hline $\begin{array}{l}\text { I actually buy new products. } \\
\text { I'm a person who tries various things. }\end{array}$ & -0.008 & -0.023 & 0.715 & -0.091 & 0.028 & 0.126 \\
\hline I check the information of new products diligently. & 0.075 & -0.024 & 0.688 & 0 & 0.074 & -0.071 \\
\hline I'm curious about how I feel from the surroundings. & 0 & 0.009 & -0.168 & 0.686 & 0.043 & -0.056 \\
\hline I often want what people around me have. & -0.041 & -0.014 & 0.253 & 0.509 & -0.136 & 0.109 \\
\hline I only want to put what I like around me. & -0.085 & 0.109 & -0.018 & 0.036 & 0.548 & 0.088 \\
\hline I think that individuality appears in what kind of shopping you do. & 0.031 & -0.012 & -0.045 & 0.112 & 0.53 & 0.091 \\
\hline Shopping often doesn't compromise until I find what I really want. & -0.059 & 0.076 & 0.144 & -0.045 & 0.529 & -0.263 \\
\hline I often buy what I like intuitively on impulse. & -0.117 & 0.043 & 0.034 & -0.067 & 0.045 & 0.802 \\
\hline I'm in trouble because what I want comes out one after another. & 0.062 & 0.009 & 0.099 & 0.264 & 0.017 & 0.295 \\
\hline $\begin{array}{l}\text { I want to have something different from the people around me as } \\
\text { much as possible. }\end{array}$ & 0.255 & -0.096 & 0.019 & -0.147 & 0.433 & 0.167 \\
\hline I like to have branded things. & 0.405 & 0.063 & 0.236 & -0.018 & -0.056 & 0.02 \\
\hline I want to improve my fashion sense. & 0.45 & 0.144 & -0.064 & 0.283 & 0.046 & -0.037 \\
\hline I want to be seen from the surroundings. & 0.458 & -0.119 & -0.077 & 0.263 & 0.159 & -0.059 \\
\hline I often shop by referring to the best-selling rankings. & -0.048 & -0.016 & 0.286 & 0.429 & -0.003 & -0.093 \\
\hline
\end{tabular}


TABLE IV. THE AVERAgE VALUE OF FACTOR SCORE ON THREE CLUSTERS

\begin{tabular}{|l|l|l|l|l|l|l|}
\hline \multirow{2}{*}{$\begin{array}{l}\text { Cluster } \\
\text { Name }\end{array}$} & \multicolumn{5}{|l|}{ Factor Score } \\
\cline { 2 - 7 } & $\begin{array}{l}\text { Show } \\
\text {-off }\end{array}$ & $\begin{array}{l}\text { Quality- } \\
\text { oriented }\end{array}$ & $\begin{array}{l}\text { Innov } \\
\text { ator }\end{array}$ & $\begin{array}{l}\text { Faddi } \\
\text { sm }\end{array}$ & $\begin{array}{l}\text { Commit } \\
\text { ment }\end{array}$ & $\begin{array}{l}\text { Intuit } \\
\text { ive }\end{array}$ \\
\hline Trend & 1.02 & 0.36 & 0.11 & -0.38 & -0.46 & -0.20 \\
\hline $\begin{array}{l}\text { Self- } \\
\text { respect }\end{array}$ & -1.02 & 0.05 & -0.03 & 0.18 & 0.34 & 0.50 \\
\hline $\begin{array}{l}\text { Conserva } \\
\text { tive }\end{array}$ & 0.18 & -0.43 & -0.09 & 0.18 & 0.07 & -0.40 \\
\hline
\end{tabular}

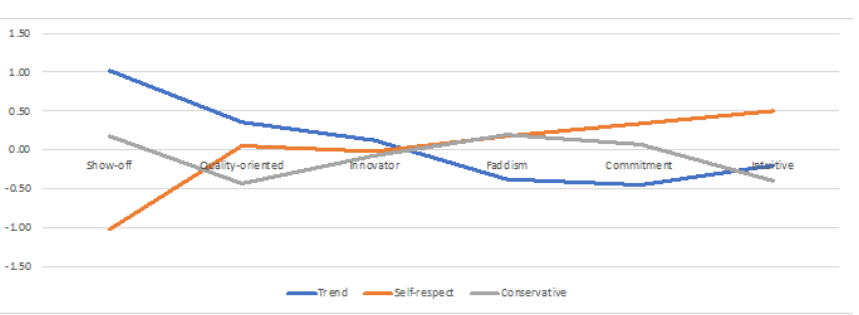

Fig. 4. Visualization of the Average Value of Factor Score on Three Clusters.

The trend cluster included 1583 people, the self-respecting cluster had 1842 people, and the conservative cluster had 1521 people. Among the 10 subjects who participated in the experiment under the same conditions, two were in the trend cluster, five were in the self-respect cluster, and three were in the conservative cluster. Furthermore, we categorized consumers into three clusters based on their values. The values of the show-off factors, quality-oriented factors, and innovator factors were high. As a result, they tend to grab new products and information and are more sensitive to fashion trends. For self-respect clusters, the values of the faddism, commitment, and intuition factors are high. It is a cluster that values one's core and sensibility while being sensitive to one's own way of seeing and the trends around oneself. Conservative clusters have only a high Faddism factor and less noticeable results for other factors. It is a cluster that likes basics and does not adventure.

\section{B. Analysis of Time Spent on Product Shelves}

To classify the differences between the clusters, we aggregated the time spent on product shelves. The results for $1 \mathrm{~F}$ are shown in Fig. 5, and the results for $2 \mathrm{~F}$ are shown in Fig. 6. The detailed results for each cluster are discussed in Section VA.

\section{Product Evaluation on Product Shelves using AOI Analysis}

Next, we conducted an area of interest (AOI) analysis to see whether there were differences in the products they were looking at on the shelves among the value clusters. The AOI analysis is a function of the eye-tracking device software Tobii Pro Lab [17], which enables us to measure the number of gazes and gazing time of the area of interest by specifying the area of interest from the recorded data [22]. Total visit duration on an information sign was found as the strongest predictor of product choice by Bridget $\mathrm{K}$. Behe et al. [23]. In this study, we extracted total visit duration of the item area for three product shelves on the first and second floors. We set two conditions as selection criteria for the three shelves: the products could not be seen from multiple directions, and there were no clusters with zero time spent on the shelves. We chose Shelf 2, Shelf 3, and Shelf 4 on the first floor, and Shelf 1, Shelf 4, and Shelf 5 on the second floor. Here, we present the results of Shelf 4 on the first floor (Fig. 7 and Table V) and Shelf 4 on the second floor (Fig. 8 and Table VI), in particular, where differences among clusters are characteristically found.

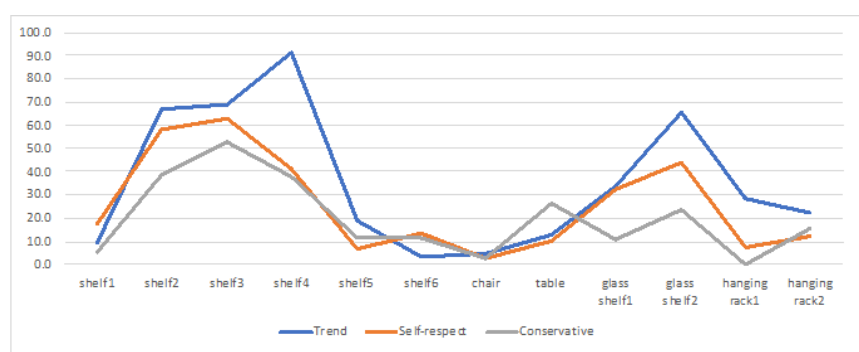

Fig. 5. Graph of Time Spent on the Product Shelves at 1F.

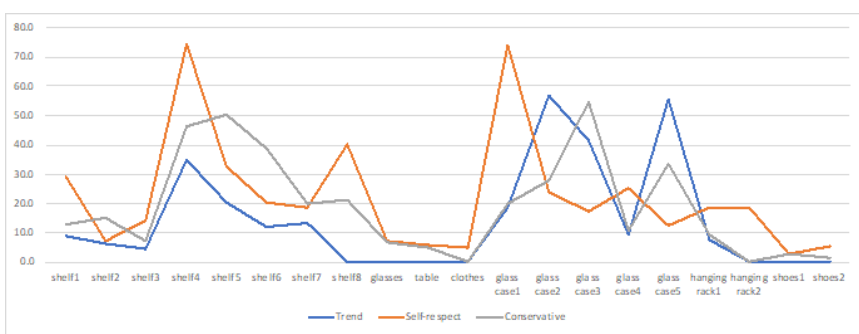

Fig. 6. Graph of Time Spent on the Product Shelves at 2F.

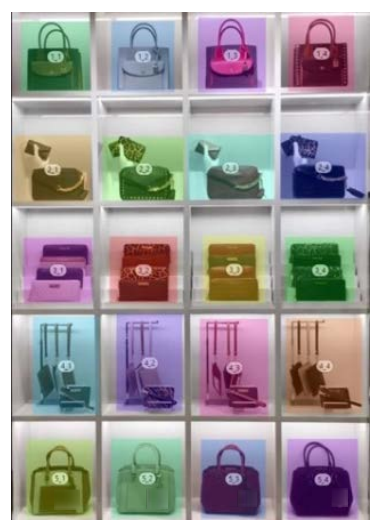

Fig. 7. Picture of Shelf 4 on the First Floor.

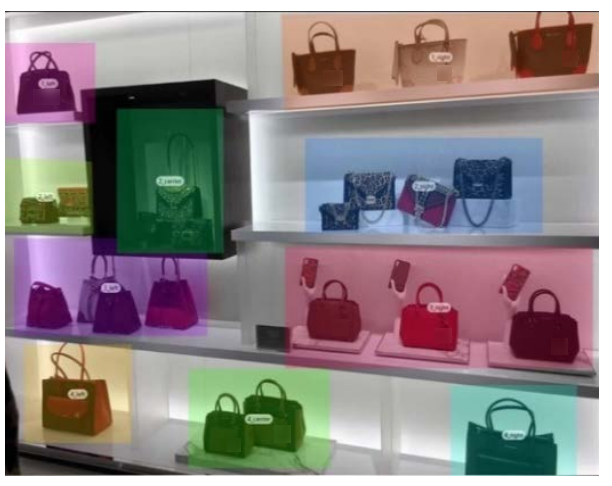

Fig. 8. Picture of Shelf 4 on the Second Floor. 
TABLE V. AOI ANALysis RESUlt OF SHELF 4 ON the First FloOR

\begin{tabular}{|c|c|c|c|c|c|c|c|c|c|c|}
\hline Cluster & 1_1 & 1_2 & 1_3 & $1 \_4$ & 2_1 & $2 \_2$ & $2 \_3$ & $2 \_4$ & 3_1 & 3_2 \\
\hline Trend & 0.00 & 0.26 & 0.55 & 0.42 & 2.06 & 1.02 & 1.32 & 2.41 & 0.70 & 1.38 \\
\hline Self-respect & 0.00 & 0.26 & 0.31 & 0.12 & 0.26 & 0.83 & 0.19 & 0.28 & 1.05 & 1.36 \\
\hline Conservative & 0.00 & 0.33 & 0.04 & 0.26 & 0.63 & 0.46 & 0.10 & 0.08 & 1.20 & 1.51 \\
\hline Cluster & 3_3 & 3_4 & 4_1 & $4 \_2$ & 4_3 & $4 \_4$ & $5 \_1$ & $5 \_2$ & 5_3 & $5 \_4$ \\
\hline Trend & 1.94 & 3.41 & 1.45 & 2.04 & 3.91 & 4.05 & 1.19 & 2.18 & 2.80 & 5.20 \\
\hline Self-respect & 1.18 & 1.57 & 1.04 & 0.77 & 0.98 & 0.64 & 1.52 & 0.31 & 0.36 & 0.17 \\
\hline Conservative & 0.44 & 0.29 & 0.24 & 0.05 & 0.47 & 0.07 & 0.17 & 0.82 & 0.26 & 0.45 \\
\hline
\end{tabular}

TABLE VI. AOI ANALYSIS RESUlt OF SHELF 4 ON THE SECOND FlOOR

\begin{tabular}{|l|l|l|l|l|l|}
\hline Cluster & 1_left & 1_right & 2_center & 2_left & 2_right \\
\hline Trend & 0.00 & 1.90 & 0.75 & 0.57 & 1.23 \\
\hline Self-respect & 0.15 & 1.85 & 1.41 & 0.82 & 2.91 \\
\hline Conservative & 0.10 & 1.58 & 0.93 & 0.61 & 1.13 \\
\hline Cluster & 3_left & 3_right & 4_center & 4_left & 0.60 \\
\hline Trend & 2.81 & 3.56 & 0.44 & 0.70 & 0.64 \\
\hline Self-respect & 2.04 & 4.67 & 1.82 & 0.24 & 0.29 \\
\hline Conservative & 2.67 & 3.99 & 1.31 & & 0.84 \\
\hline
\end{tabular}

TABLE VII. The Tendency OF THE ORder OF GAZE AMONG THE Clusters

\begin{tabular}{|c|c|c|c|}
\hline Subject No. & Cluster Affiliation & Action & Comparison Tendency \\
\hline 1 & Trend & $\begin{array}{l}\text { The first time, she looked at all the products, } \\
\text { and then compared them with the black products; } \\
\text { the second time, she focused on the camera bag on the fourth shelf. }\end{array}$ & $\begin{array}{l}\text { Compare shapes } \\
\rightarrow \text { Compare colors }\end{array}$ \\
\hline 2 & Trend & She focused on the red and beige products. & Compare shapes \\
\hline 3 & Self-respect & $\begin{array}{l}\text { The first time, she compared shapes (black, red, and white); } \\
\text { the second time, she compared the chain bag and then the camera bag. }\end{array}$ & $\begin{array}{l}\text { Compare shapes } \\
\rightarrow \text { Compare colors }\end{array}$ \\
\hline 4 & Self-respect & She compared vertically and compared colors by shape & Compare colors \\
\hline 5 & Self-respect & She compared the same color to each other & Compare shapes \\
\hline 6 & Self-respect & $\begin{array}{l}\text { She barely looked at the beige product in the first row; } \\
\text { she focused on the camera bags in the second and fourth rows }\end{array}$ & Compare colors \\
\hline 7 & Self-respect & $\begin{array}{l}\text { After she compared the camera bags in the second and fourth rows, } \\
\text { she touched the products in } 4 \_4 \text { and compared the chain bag }\end{array}$ & Compare colors \\
\hline 8 & Conservative & After looking at them, she touched 2_3 and 3_2 & $\begin{array}{l}\text { Don't look at anything but the } \\
\text { product she was interested in }\end{array}$ \\
\hline 9 & Conservative & $\begin{array}{l}\text { She looked mainly at the camera bags on the second and fourth rows, } \\
\text { then looked at the chain shoulder a little }\end{array}$ & Compare colors \\
\hline 10 & Conservative & $\begin{array}{l}\text { After looking at the whole, she compared the black products, } \\
\text { and then touched 3_4 for the second time, comparing the color of the camera bag }\end{array}$ & $\begin{array}{l}\text { Compare shapes } \\
\rightarrow \text { Compare colors }\end{array}$ \\
\hline
\end{tabular}

The AOI analysis includes a function to visualize the order in which the viewpoints were moved in each area for a single product shelf. We compared the tendency of the order of gaze among the clusters. In this study, we analyzed Shelf 5 on the second floor, where shoulder bags were lined up in the same shape as the products. The results are listed in Table VII. The results showed that there were four patterns of product comparison methods: those who compared shapes with colors, those who compared shapes, those who compared colors, and those who gazed at only the most visible product for a long time. However, there were no differences among clusters.

\section{DisCUSSION OF ANALYSIS RESUlts AND PROPOSALS FOR PRODUCT PlaCEMENT AND CUSTOMER SERVICE METHODS BASED ON EXPERIMENTS}

This section discusses the results of the analysis described in section IV. Specifically, this study clarifies the relationship between consumers' sense of value and searching behavior. In addition, based on the results of the analysis and consideration, we propose a shelf arrangement in the store. 


\section{A. Discussion of the Relationship between Consumer Values and Product Search Behavior}

Based on the results of Section IVB, we found that the product shelves that are easily gazed at tend to be gazed at in all clusters. Shelves 2, 3, and 4 on the first floor and Shelf 4 on the second floor are the product showcases where people spend the most time. Therefore, the shelves with multiple types of bags facing the front left-hand wall from the entrance are in the golden zone, where they are easily gazed at and searched. In contrast, we found that the time spent in the product shelves of collaboration products, men's products, clothes, and collection products that emphasize the attractiveness of the brand are short. From the results in Section IVC, the overall tendency of the results is that flashy products are more likely to attract attention in all clusters. Therefore, when placing products, combining eye-catching products with products that attract attention can effectively increase the chances of customers discovering the products. In addition, the height of the product shelves that are most likely to be gazed at correspond to the products on the second to third shelves from the top. This result was similar to the study of Piotr Chynał et al. [24]. This shows that the location of the product shelf and its position on the shelf are also important for optimal product placement. Table VIII shows the summary of product search behavior.

In the trend cluster, the results of Section IVB show that the time spent in the product shelves with small bags, small items, and wrist watches was longer. The results of Shelf 4 on the first floor show that it has the largest bias in terms of the time spent on the products, indicating that it is the cluster that tends to compare the products it likes. As for bags, there is a tendency to prefer small handbags and shoulder bags to large ones. This may reflect the recent trend for smaller bags rather than larger bags. In the self-respect cluster, the time spent on shelves with flashy bags and small items was long. Based on the results of Shelf 1 and Shelf 4 on the second floor, the self-respect cluster was the only cluster that often looked at shoes. In addition, the results of Shelf 4 on the second floor showed that they tended to look at products with patterns and flashy colors more often than other clusters. This may have been influenced by the concept of the fashion brand in this experiment as a self-respect cluster. As for the conservative cluster, the shelf-gazing time was shorter than that of the other clusters, indicating that they tended to look at the shelves from a bird's-eye view. The conservative cluster tended to pay more attention to the eyecatching products. The conservative cluster tended to look at products from a bird's-eye view and did not pay attention to any product for a long time, resulting in the least bias. Therefore, the conservative cluster reflected the tendency to prefer basic products and not to try new or flashy products.

\section{B. Suggestion for Product Placement and Customer Service Methods based on Experiments}

The display of trendy and recommended products on the product shelves of the first floor is necessary to present the brand concept. However, no one in any of the clusters gazed at the display for a long time to search for products. Therefore, it is effective to place the product shelves near the entrance to present the concept, and to arrange the products around the shelves so that they can be easily compared. Table IX shows the summary of suggestion based on experiments.

TABLE VIII. SUMMARY OF PRODUCT SEARCH BEHAVIOR

\begin{tabular}{|l|l|l|}
\hline Cluster Name & $\begin{array}{l}\text { Characteristics of product shelves } \\
\text { with long staying time }\end{array}$ & $\begin{array}{l}\text { Characteristics of products that } \\
\text { are likely to attract attention }\end{array}$ \\
\hline Trend & There're small bags, small items, and wrist watches. & Size: small \\
\hline Self-respect & There're flashy bags and small items. & $\begin{array}{l}\text { Colors: flashy, bright, patterned cloth } \\
\text { Category: shoes }\end{array}$ \\
\hline Conservative & No bias compared to other clusters. & They don't gaze at any product for a long time. \\
\hline
\end{tabular}

TABLE IX. SUMMARY OF SUGGESTION BASED ON THE EXPERIMENTS

\begin{tabular}{|l|l|l|}
\hline Cluster Name & Product Placement Method & Customer Service Method \\
\hline Trend & $\begin{array}{l}\text { Placing products of multiple colors and shapes in the same place } \\
\text { for easy comparison }\end{array}$ & Present products in a way that makes them easy to compare \\
\hline Self-respect & $\begin{array}{l}\text { Placement of recommended products in combination with eye- } \\
\text { catching products }\end{array}$ & To introduce trends and popular products. \\
\hline Conservative & $\begin{array}{l}\text { To place together products that are easy to coordinate, flashy } \\
\text { products that catch the eye, and products that are recommended }\end{array}$ & To combine products and present them as coordinated \\
\hline
\end{tabular}


Since the trend cluster tends to compare products they like, it is effective to place products of multiple colors side by side so that they can be easily compared and place trend products on the second to third height from the top where they can be easily seen. In terms of customer service, since customers often tend to compare products, it is considered effective to talk to them and recommend products to them when they have narrowed down their search. In addition, it is good to compare and recommend products with the same tendency as the products customers like. Self-esteem clusters tend to pay attention to products with flashy colors and patterns that are likely to catch their eyes, and thus, it is effective to present trends and recommendations in an easy-to-understand manner. Therefore, it would be beneficial to place recommended products in combination with eye-catching products and place products on the shelves in a conspicuous manner. In terms of customer service, it is important to inform customers of the current trend and popular products. The conservative cluster often looks at products from a bird's-eye view more than any other cluster, and thus, it would be beneficial to arrange products in such a way as to increase opportunities to encounter products, for example, by not placing similar shapes and colors of products together, so that customers can see a full range of products. Products that are easy to match as coordinates or flashy products that easily catch the eye and recommended products should be placed together. In terms of customer service, it is also important to recommend combinations of products and to encourage customers to compare products when they stop by so that they can find their favorite color or shape.

\section{CONCLUSION AND FUTURE WORK}

We aimed to clarify the relationship between customer values and product search behavior and proposed product placement and customer service methods based on their values. The results showed that product search behavior differed based on three types: trend cluster, self-esteem cluster, and conservative cluster. Trend clusters tended to observe and compare products more closely and had greater variability in product gazing time. Self-esteem clusters tended to look at products with patterns and flashy colors more often than other clusters. The conservative cluster tended to look at products from a bird's-eye view and did not pay attention to any product for a long time, resulting in the least bias. In addition, we proposed product placement in a store considering the features of these clusters.

In future work, we need to understand what kind of values the customers who use the store tend to have. Therefore, we think that it is necessary to speculate using purchase data, analyze the difference in the initial movement of product search for each sense of value, and analyze the reaction to customer service in future work.

\section{ACKNOWLEDGMENT}

We thank the target store for this study, employees of this store and participants of this experiment for providing experimental opportunity. This work was supported by JSPS KAKENHI Grant Number 19K01945, $21 \mathrm{H04600}$ and $21 \mathrm{~K} 13385$.

\section{REFERENCES}

[1] Ministry of Economy, Trade and Industry, Commerce and Information Policy Bureau, the Information Economy Division, Development of infrastructure for data-driven society in Japan (market research on electronic commerce) in 2018, p. 49, https:/www.meti.go.jp/press/ 2019/05/20190516002/20190516002-1.pdf (viewed 27 July 2021).

[2] Ministry of Economy, Trade and Industry, Commerce and Information Policy Bureau, the Information Economy Division, "International economic research project (market research on electronic commerce) related to the construction of an integrated economic growth strategy inside and outside the country in the first year of Reiwa”, pp. 33-35, https://www.meti.go.jp/press/2020/07/20200722003/20200722003-1.pdf (viewed 27 July 2021).

[3] Aubrey, Chris and Judge, David (2012, March 1), "Re-imagine retail: Why store innovation is key to a brand's growth in the 'new normal', digitally-connected and transparent world," In the Journal of Brand Strategy, Volume 1, Issue 1.

[4] M. Fuentes-Blasco, B.Moliner-Velázquez, D. Servera-Francés, I. GilSaura (2017), "Role of marketing and technological innovation on store equity, satisfaction and word-of-mouth in retailing," Journal of Product \& Brand Management, 26(6), 650-666, https://doi.org/ 10.110 8/JBM07-2016-1279.

[5] Myoung-a An, Sang-Lin Han (2020), "Effects of experiential motivation and customer engagement on customer value creation: Analysis of psychological process in the experience-based retail environment," Journal of Business Research Volume 120, November 2020, Pages 389397, https://doi.org/10.1016/j.jbusres.2020.02.044.

[6] Pierre Chandon, J. Wesley Hutchinson, Eric T. Bradlow, Scott H. Young (2009), "Does In-Store Marketing Work? Effects of the Number and Position of Shelf Facings on Brand Attention and Evaluation at the Point of Purchase,” J. Marketing 73 (6), 1-17, https://doi.org/10.1509 /jmkg.73.6.1.

[7] A. Matsumoto (2004), "Factors Affecting Consumer Satisfaction in the Apparel Purchase of Young Persons.”, Journal of the Japan Research Association for Textile End-Uses, Vol. 45, pp. 829-836, (in Japanese), https://doi.org/10.11419/senshoshi1960.45.829.

[8] M. Ando (2013), "Impression of Attitude toward Staff and Hospitality Service due to Differences in Values for Hotel Services.”, Proceedings of the 1st National Convention of Society for Serviceology, pp. 144-147, (in Japanese), http://www.robot.t.u-tokyo.ac.jp/asamalab/publications/ files/855.pdf.

[9] Huddleston Patricia, Behe Bridget K, Minahan Stella, Fernandez R Thomas (2015), "Seeking attention: an eye tracking study of in-store merchandise displays," International Journal of Retail \& Distribution Management; 2015 Vol. 43 (6), http://dx.doi.org/10.1108/IJRDM-062013-0120.

[10] Zuschke N. (2020), “The impact of task complexity and task motivation on in-store marketing effectiveness: An eye tracking analysis,” Journal of Business Research, 116, 337-350. doi:10.1016/j.jbusres.2020.05.009.

[11] Bialkova, S., Grunert, K.G., van Trijp, H. (2019), "From desktop to supermarket shelf: Eye-tracking exploration on consumer attention and choice,” Food Quality and Preference, https://doi.org/10.1016/ j.foodqual.2019.103839.

[12] Tupikovskaja-Omovie Z. and Tyler, D. (2020), "Clustering consumers' shopping journeys: eye tracking fashion m-retail", Journal of Fashion Marketing and Management, Vol. 24 No. 3, pp. 381-398. https://doi.org/10.1108/JFMM-09-2019-0195.

[13] Yoon Min Hwang \& Kun Chang Lee (2018) “Using an Eye-Tracking Approach to Explore Gender Differences in Visual Attention and Shopping Attitudes in an Online Shopping Environment,” International Journal of Human-Computer Interaction 2018, VOL. 34, NO. 1, 15-24, https://doi.org/10.1080/10447318.2017.1314611.

[14] Bao-Rui Li, Wang Yi, Ke-Sheng, Wang (2017), “A novel method for the evaluation of fashion product design based on data mining," Advances in Manufacturing; Shanghai vol.5, no. 4, pp. 370-376, https://doi.org/10.1007/s40436-017-0201-x.

[15] O'Cass, A. (2004), "Fashion clothing consumption: antecedents and consequences of fashion clothing involvement", European Journal of 
$\begin{array}{lllll}\text { Marketing, } & \text { Vol. } & 38 & \text { No. } & 7 \text { 7, pp. }\end{array}$ https://doi.org/10.1108/03090560410539294.

[16] Tobii inc. "Tobii Pro Glasses 2 wearable eye tracker," https://www.tobiipro.com/product-listing/to- bii-pro-glasses-2/ (viewed 27 July 2021).

[17] Tobii inc. “Tobii Pro Lab software,” https://www.tobiipro.com/productlisting/tobii-pro-lab/ (viewed 27 July 2021).

[18] N. Saijo, T. Tosu, K. Morimura, K. Otake, T. Namatame (2018) "Evaluation of Store Layout Using Eye Tracking Data in Fashion Brand Store.” In: Meiselwitz G. (eds) Social Computing and Social Media. User Experience and Behavior. SCSM 2018. Lecture Notes in Computer Science, vol 10913. Springer, Cham. https://doi.org/10.1007/978-3-31991521-0_11.

[19] D. Kimura, K. Shibata (2019), “Relationships between Consumers’ ProEnvironmental Behaviors and Daily Life Values”, Journal of Life Cycle Assessment, Japan, Vol. 15 No. 2, pp. 199-210, (in Japanese), https://doi.org/10.3370/lca.15.199.
[20] E. Matsuoka, H. Yamamoto (2020), “A study on the Behavior of Fashion Emotional Value by the Classification of Lifestyle”, Journal of the Japan Society of Sensory Engineering, Vol. 19 No. 3, pp. 281-289, (in Japanese), https://doi.org/10.5057/jjske.TJSKE-D-19-00052.

[21] L. Ding and R. Beichner, “Approaches to data analysis of multiplechoice questions,” phys. Rev. ST Phys. Educ. Res 5, 020103, 2009, https://doi.org/10.1103/PhysRevSTPER.5.020103.

[22] Magdalena Borys, Małgorzata Plechawska-Wójcik (2017), "Eyetracking metrics in perception and visual attention research,” European Journal of Medical Technologies 2017, Vol.3 No.16, pp. 11-23.

[23] Bridget K. Behe, Mikyeung Bae, Patricia T. Huddleston, Lynnell Sage (2015), "The effect of involvement on visual attention and product choice,” Journal of Retailing and Consumer Services, 24, 10-21, https://doi.org/10.1016/j.jretconser.2015.01.002.

[24] Chynal P., Janusz S., Rymarz M. and Kilijańska B. (2016), "Shopping behaviour analysis using eyetracking and EEG”, Proceedings of 2016 9th International Conference on Human System Interactions, pp. 458464. 